\title{
AN OVERVIEW OF ACCOUNTING ETHICS COURSE IN UNDERGRADUATE PROGRAM CURRICULUM IN INDONESIA
}

\author{
Amelia Limijaya \\ Parahyangan Catholic University \\ amelia.limijaya@unpar.ac.id
}

Received: 01-02-2018

Revised: 27-03-2018

Accepted: $17-04-2018$

\section{ABSTRACT}

This research describes the status of accounting ethics course in accounting undergraduate program curriculum in Indonesia. To obtain the population of accounting undergraduate programs (bachelor's degree) in Indonesia, the author relies on the data available from the National Accreditation Agency for Higher Education (BAN-PT) website. Of approximately 600 programs that make up the population, a sample of 60 programs were chosen. Information regarding accounting ethics course from these 60 programs was taken from each program's website. Based on the analysis that was performed, there are three major findings: (1) the majority of the programs do offer an accounting-specific ethics course but only a few of them who have two stand-alone courses on ethics in their curriculum (2) there are similarities from one program to another regarding the course name and (3) variations are observed regarding the course placement, nature of the course and the required prerequisites. The author suggests the programs to include accounting ethics topic in the curriculum, preferably in a stand-alone course, or to integrate it into other courses if a stand-alone one is not feasible, as well as to make sure that the learning outcomes related to accounting ethics are actually covered.

Keywords: accounting ethics; accounting undergraduate program; curriculum

\section{ABSTRAK}

Penelitian ini mendeskripsikan status mata kuliah etika akuntansi di kurikulum program studi sarjana akuntansi di Indonesia, yang didasari oleh data yang tersedia di situs Badan Akreditasi Nasional Perguruan Tinggi. Terdapat sampel 60 program studi yang memiliki status akreditasi A dan status tersebut belum kadaluarsa. Hasil penelitian menunjukkan bahwa mayoritas program studi memiliki mata kuliah spesifik etika akuntansi dan hanya beberapa yang memiliki dua mata kuliah terkait etika dalam kurikulumnya. Tidak banyak perbedaan yang diamati dalam hal penamaan mata kuliah. Terdapat variasi dalam hal penempatan mata kuliah, sifat serta mata kuliah prasyarat. Saran yang diberikan adalah memasukkan topik etika akuntansi dalam kurikulum, dengan preferensi sebagai mata kuliah tersendiri, atau mengintegrasikannya ke mata kuliah lain dan memastikan capaian pembelajaran terkait etika akuntansi terpenuhi.

Kata kunci: etika akuntansi; program studi sarjana akuntansi; kurikulum

How to cite: Limijaya, A. (2018). An Overview Of Accounting Ethics Course In Undergraduate Program Curriculum In Indonesia. Akrual: Jurnal Akuntansi. 9 (2): 95-110.doi: http://dx.doi.org/10.26740/jaj.v9n2.p95-110

\section{INTRODUCTION}

Ethics is an important concept because it serves as a guidance to distinguish good from bad or right from wrong in a decision-making process. Ethics “... is concerned with right or wrong, good or bad. It is either a set of principles held by an individual or group or the discipline that studies those ethical principles" (Duska, Duska \& Ragatz 2011, p. 34). Similarly, Mintz and Morris (2014 pp. 5-6) as well as Klein (2016, p. 
2) state that ethics can help people to distinguish right from wrong, good from bad, just from unjust, and can be related to the morality concept. People need some kind of standards or references to help them decide whether an action is right or wrong. In other words, ethics tends to be normative or prescriptive in nature (what should be done). This understanding of ethics can be applied generally in daily lives.

Aside from the general ethics, commonly there is also specific ethics for certain professions. With regards to professional work life, each profession ideally has its own code of ethics to be adhered by the professionals in each respective fields, one of which is the accounting profession. The importance of ethics in this particular profession is highlighted due to the profession's role to serve public interest. Nevertheless, despite the existence of code of ethics for accountants, accounting scandals still emerge. A series of accounting scandals, such as Enron, WorldCom, etc. damaged the reputation of the accounting profession in the public eye. The International Federation of Accountants (IFAC) even had to form the Task Force on Rebuilding Public Confidence in Financial Reporting with the purpose to address, from an international perspective, the loss of credibility in financial reporting and approaches to resolving the problem (IFAC 2003). The prevalence of accounting scandals may indicate a lack of attention given to as well as understanding of code of ethics for accountants.
The accounting profession, through standard setters as well as regulators and other organizations, continuously develops efforts to restore and improve public trust to the profession, one of which is through accounting ethics education. In the academic context, the topic of accounting ethics is usually included in the curriculum as one of the means to expose students to the importance of ethics in a decision-making process of an accountant. Some academia chose to have a stand-alone accounting ethics course (such as Chawla, Khan, Jackson, Gray III 2015; Dellaportas 2006; Levy \& Mitschow 2008), as this approach could help students develop their ethical reasoning skills better. However, having a stand-alone ethics course may not be feasible for some academic due to a number of factors, for example the lack of time and related resources, the curriculum which is already packed with many other technical accounting subjects, or the lack of ability and expertise of the subject matter (Blanthorne 2017; Graham, Kelly, Massey, Van Hise 2014). Thus, alternatively, an integration approach may be preferred instead of a standalone one, i.e. to include the accounting ethics topic in other accounting courses.

The understanding and awareness of accounting ethics does not just matter when a student is studying at a university. Moreover, the testament of ethical behavior as accountants is tested in the workplace when they are faced with an ethical situation. Therefore, for professionals, the awareness of ethics needs to be continually 
emphasized through various means. One of which is by the code of ethics/ code of conduct developed by their employers that must be adhered to. Also, professional associations (bodies) usually organize many continuing professional development/ education (CPD/ CPE) activities on various topics, including accounting ethics. In general, there are some sort of rules set by the bodies that require accounting professionals to participate in the $\mathrm{CPD} / \mathrm{CPE}$. To the least extent, this could serve as one the mechanisms to continually remind the importance of accounting ethics to the professionals.

Despite the efforts put to improve accounting ethics education, both in the academic and professional context, there might be a viewpoint that this area is yet to be developed into its full potential and does not gain much attention or priority it deserves from several parties such as regulators, academicians, and practitioners (Bean \& Bernardi 2005; Bernardi \& Bean 2006). In other words, there are rooms to improve this area. There are several topics that can be explored in regards to accounting ethics education, such as the course structure, learning methods, the perspectives of practitioners and academicians to the issue, etc.

For the purpose of this research, the author is interested to explore the accounting ethics education in the academic context. Specifically, the research questions are as follows:
1. How is the accounting ethics course put in the accounting undergraduate curriculum in Indonesia?

2. What is the status of accounting ethics course in the accounting undergraduate curriculum in Indonesia?

In accordance with the research questions, the research objectives are:

1. To explain the position of accounting ethics course in the accounting undergraduate curriculum in Indonesia.

2. To describe the status of accounting ethics course in the accounting undergraduate curriculum in Indonesia.

This is a preliminary research that is conducted to serve as a starting point for a broader research on the issue of interest, i.e. accounting ethics education development in Indonesia. The author expects to develop a proposed model for accounting ethics education in accounting undergraduate curriculum in Indonesia. In order to achieve the end result, a preliminary assessment is needed to get an overview of the current state of accounting ethics education in accounting undergraduate curriculum, which is the topic of this research.

\section{LITERATURE REVIEW}

Standards and Code of Ethics for Accountants

Several organizations issue standards as well as code of ethics for accountants. Below are some of them, both within global and national (Indonesian) context. 
Handbook of the Code of Ethics for Professional Accountants (2016 Edition)

This handbook is developed by the International Ethics Standards Board for Accountants (IESBA) and published by the IFAC. Professional accountants must adhere to these codes when performing their duties. The handbook consists of three parts: Part A General Application of the Code, Part B Professional Accountants in Public Practice, and Part C - Professional Accountants in Business.

\section{Handbook of International Education}

Pronouncements (2017 Edition)

This book is developed by the International Accounting Education Standards Board (IAESB) and also published by the IFAC. In this book, there are 8 International Education Standards (IES). Of particular interest in this paper is the IES 4, Initial Professional Development Professional Values, Ethics, and Attitudes, which states 5 fundamental principles of professional ethics: integrity, objectivity, professional competence and due care, confidentiality, and professional behavior (paragraph 4). In paragraph 11, it also sets out the learning outcomes associated with professional values, ethics, and attitudes, as can be seen below in Table 1 .

Table 1. Learning Outcomes for Professional Values, Ethics, and Attitudes

\begin{tabular}{ll}
\hline Competence & \multicolumn{1}{c}{ Learning Outcomes } \\
Area (Level of & \\
Proficiency) & \\
\hline $\begin{array}{ll}\text { (a) Professional } & \text { (i) Apply a questioning mindset } \\
\text { skepticism and } & \text { critically to assess financial } \\
\text { professional } & \text { information and other relevant }\end{array}$
\end{tabular}

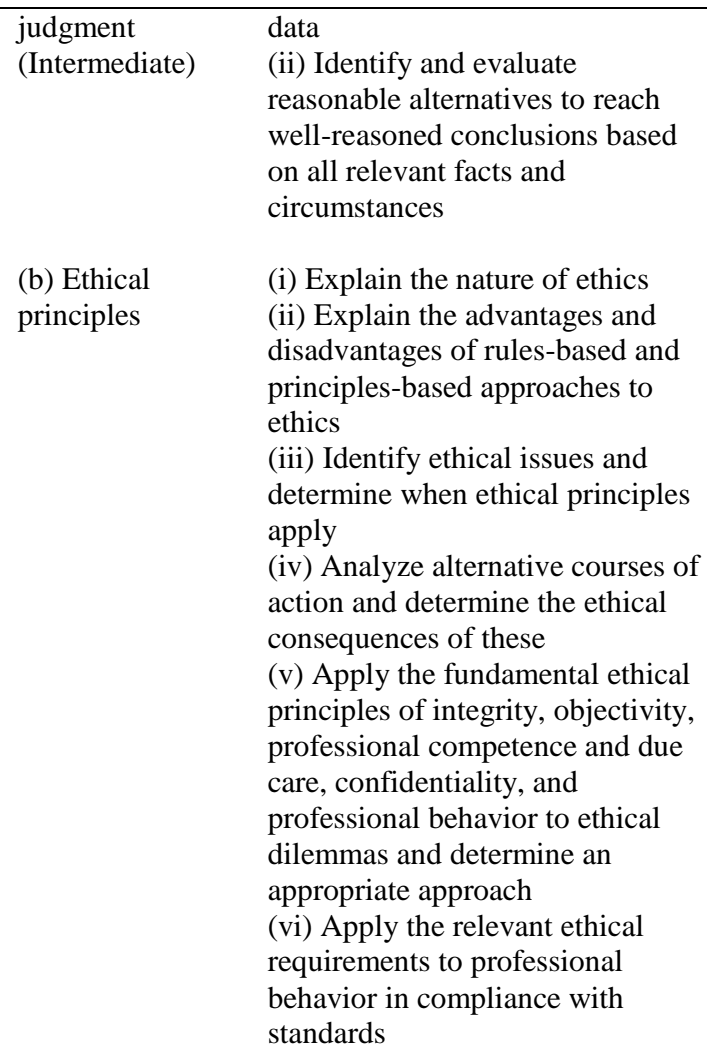

(b) Ethical

principles

(i) Explain the nature of ethics

(ii) Explain the advantages and disadvantages of rules-based and principles-based approaches to ethics

(iii) Identify ethical issues and determine when ethical principles apply

(iv) Analyze alternative courses of action and determine the ethical consequences of these

(v) Apply the fundamental ethical principles of integrity, objectivity, professional competence and due care, confidentiality, and professional behavior to ethical dilemmas and determine an appropriate approach (vi) Apply the relevant ethical requirements to professional behavior in compliance with standards

(c) Commitment
to the public
interest

(Intermediate)

(i) Explain the role of ethics within the profession and in relation to the concept of social responsibility

(ii) Explain the role of ethics in relation to business and good governance

(iii) Analyze the interrelationship of ethics and law, including the relationship between laws, regulations, and the public interest (iv) Analyze the consequences of unethical behavior to the individual, the profession, and the public

Source: IAESB 2017, pp. 55-56

\section{Professional Accountants Code of Ethics (Institute of Indonesia Chartered Accountants)}

This book is developed by the Institute of Indonesian Chartered Accountants (Ikatan Akuntan Indonesia- IAI) with reference to the Handbook of the Code of Ethics for Professional Accountants (2016 Edition), hence the structure and content is similar with several exceptions. 


\section{Accounting Ethics Education}

Many stakeholders acknowledge the importance of accounting ethics education, among them are practitioners or accounting professionals, academicians, professional accounting bodies, as well as accounting students. From academicians and practitioners' perspective, there is an increase in the demand for courses related to corporate governance and ethics (Rezaee, Szendi \& Zhang 2015). Further, a research conducted by Abdolmohammadi and Reinstein (2012) concluded that based on accounting professionals' perspective, ethics subject can have an impact on one's attitudes and behavior, although it cannot be ascertained that one would not do unethical conduct just because he/ she had studied ethics before (as also pointed out by Bean \& Bernardi 2007; Koumbiadis \& Pandit 2014). Due to the importance of ethics education, The Association to Advance Collegiate Schools of Business (AACSB) formed a task force on ethics education which recommended business schools to continuously improve business ethics education and also asked the schools to show their commitment to ethics (AACSB Ethics Education Task Force 2004). In fact, there are also some requirements related to ethics that must be fulfilled in order to be eligible for AACSB international accreditation, whether it is for business or accounting accreditation (AACSB 2016; AACSB 2017). Various accounting professional associations also address ethics-related course in their syllabus, whether as a separate module or integrated into other topics.

Regarding the accounting ethics course format, in general there are two point of views, i.e. a stand-alone course and an integrated one. Levy and Mitschow (2008) as well as Bean and Bernardi (2005) were in favor of the first view, in which a two-course ethics course is needed for accounting students, i.e. a general business ethics during junior year and accounting-specific in senior year. Also in agreement with the standalone view are Chalwa, Khan, Jackson, Gray III (2015) in addition to combining it with the integration format; Dellaportas (2006), who found that a discrete accounting ethics course has a positive impact on moral reasoning and development; Klimek \& Wennel (2011), who concluded that students taking a stand-alone course appear to have higher ethical reasoning ability than their counterparts who only took an integrated one. On the contrary, McDonald (2004) was in favor of integrating accounting ethics into other subjects in the curriculum, who presented a case of integrating ethics through a six-stage process. Moreover, Blanthorne (2017) did not prefer a specific format, rather she focused on who should teach, what to be taught and how it should be taught. IFAC (2006) gave a summary of different approaches to teaching ethics as described in Table 2.

Given its importance, then accounting ethics warrants an equal place in the curriculum as other subjects which are more accountingtechnical; professional associations even 
believed that ethics should be a compulsory course in the pre-qualifying program (Jackling, Cooper, Leung \& Dellaportas 2007). However, despite its importance, ethics is somewhat lacking the attention that it should deserve, both in terms of faculty's attention and academicians' research interest (Bean \& Bernardi 2005; Bernardi \& Bean 2006). Some impeding factors may include: uncertainty of the course content or materials; lack of time, knowledge, expertise and space in existing curriculum; the perception that ethics is still regarded as secondary to financial accounting topics; lack of financial and moral support to develop ethics course and so on (Abdolmohammadi \& Reinstein 2012; Blanthorne 2017; Rezaee, Szendi \& Zhang 2015; Dellaportas 2006; Graham, Kelly, Massey \& Van Hise 2014). Despite its underrated position, to some extent the topic of accounting ethics is present in the curriculum, although there is a gap between what is being taught and what should be taught (Nicholson \& DeMoss 2009).

Table 2. Comparison of Approaches to Ethics Education

\begin{tabular}{|c|c|c|}
\hline Strengths & Potential negatives & Neutralization \\
\hline \multicolumn{3}{|l|}{ Compulsory Subject } \\
\hline Simple administration & Seen as 'the ethics course' & $\begin{array}{l}\text { Encourage discussion of leadership, ethics, } \\
\text { and corporate responsibility in all first year } \\
\text { courses } \\
\text { Clear objectives set }\end{array}$ \\
\hline Ensures focus & $\begin{array}{l}\text { Failure to discuss issues as they arise } \\
\text { across all courses may feed cynicism }\end{array}$ & $\begin{array}{l}\text { Course to be made relevant with practical } \\
\text { examples and cases }\end{array}$ \\
\hline Careful teaching of reasoning process & $\begin{array}{l}\text { Become mechanical in decision- } \\
\text { making }\end{array}$ & Emphasize the internalization of reasoning \\
\hline Strong signal of commitment & $\begin{array}{l}\text { Reduce curriculum space for other } \\
\text { technical areas }\end{array}$ & $\begin{array}{l}\text { Skill-based learning to avoid rote learning } \\
\text { but focus on competency }\end{array}$ \\
\hline Energizes student's interest & Perceived as soft options & $\begin{array}{l}\text { Highlight the significance of judgment in } \\
\text { accounting and related areas }\end{array}$ \\
\hline Faculty learning opportunity & Research interest not appreciated & Promotion of ethics education and research \\
\hline \multicolumn{3}{|l|}{ Elective Subject } \\
\hline Opportunity for advanced study & $\begin{array}{l}\text { Many students do not take the } \\
\text { electives }\end{array}$ & $\begin{array}{l}\text { Include a compulsory course in leadership, } \\
\text { ethics, and corporate responsibility at the } \\
\text { outset of the program }\end{array}$ \\
\hline $\begin{array}{l}\text { Source of tested material for use in } \\
\text { first year compulsory course }\end{array}$ & $\begin{array}{l}\text { Because they are usually taken late in } \\
\text { the program, electives have limited } \\
\text { impact }\end{array}$ & $\begin{array}{l}\text { Integrate discussion of ethics issues into all } \\
\text { first year students }\end{array}$ \\
\hline Opportunity for specialization & Regarding ethics as an option & Promote interest \\
\hline \multicolumn{3}{|l|}{ Integration with Existing Subjects } \\
\hline $\begin{array}{l}\text { Demonstrate that dilemmas and } \\
\text { questions are not isolated problems, } \\
\text { but present throughout the } \\
\text { organization }\end{array}$ & $\begin{array}{l}\text { Fragmented teaching yields } \\
\text { fragmented understanding of the } \\
\text { issues and reasoning process; no } \\
\text { theoretical underpinning to handle } \\
\text { potentially for change }\end{array}$ & $\begin{array}{l}\text { Include a compulsory course in leadership, } \\
\text { ethics, and corporate responsibility at the } \\
\text { outset of the MBA program }\end{array}$ \\
\hline $\begin{array}{l}\text { Prima facie evidence for ethical } \\
\text { attention by the profession }\end{array}$ & $\begin{array}{l}\text { Treatment of topics by many } \\
\text { instructors tends to be intermittent and } \\
\text { superficial }\end{array}$ & $\begin{array}{l}\text { More discussion of cases to appreciate the } \\
\text { significance of an ethical framework }\end{array}$ \\
\hline $\begin{array}{l}\text { Indicates certain interest in managerial } \\
\text { decision making process }\end{array}$ & $\begin{array}{l}\text { Often rhetorical approach without } \\
\text { substance }\end{array}$ & \\
\hline
\end{tabular}




\section{RESEARCH METHOD}

To conduct this research, the author relies on the data available on the National Accreditation Agency for Higher Education website (NAAHE, or Badan Akreditasi Nasional Perguruan Tinggi - BAN-PT in Indonesian). Here, one can see the accreditation status of a particular program of interest. In this research, the program of interest is accounting undergraduate program (bachelor's degree). Below are the steps that were taken to obtain the list of all accounting undergraduate programs in Indonesia:

1. Open the following website address https://banpt.or.id/direktori/prodi/pencarian prodi

(All data retrieved from this website is as per 14 December 2017)

2. Filter the $3^{\text {rd }}$ column 'Strata', to display only S1 (bachelor's degree)

3. All other columns were not changed from the default settings

The above steps resulted in 616 programs. Then the author tried to break down these 616 programs into different accreditation expiry status, by applying filter feature in the $9^{\text {th }}$ column 'Status Daluarsa' which results in the following table:

Table 3. Number of Programs at All Ranks with Various Expiry Status

\begin{tabular}{ccc}
\hline Rank $^{1)}$ & Expiry Status $^{2)}$ & Number of Programs \\
\hline All & All & 616 \\
All & Not expired yet & 552 \\
& & $\begin{array}{c}\text { (includes 21 not expired } \\
\text { yet but in the process of } \\
\text { reaccreditation) }\end{array}$ \\
All & Expired & 14
\end{tabular}

$\begin{array}{ccc}\text { All } & \begin{array}{c}\text { Reaccreditation } \\ \text { process }\end{array} & \begin{array}{c}19 \\ \text { (does not include those } \\ \text { which are still not } \\ \text { expired yet but in the } \\ \text { process of } \\ \text { reaccreditation) }\end{array} \\ \text { All } & \begin{array}{c}6 \text { months prior to } \\ \text { expiry date }\end{array} & 31\end{array}$

1) Comprises of 3 ranks: A (very good, score of 361400), B (good, score of 301-360), C (fair, score of 200-300)

2) Comprises of 4 statuses: not expired yet, expired, reaccreditation process, 6 months prior to expiry date Source: processed by author

There are 14 programs which are already expired but not in the process of reaccreditation, so the author decided to exclude them. The assumption is that those programs have ceased to operate. Thus, in total there are 602 programs to be observed. Of this amount, the author broke them down into rank types by applying the filter function in the $7^{\text {th }}$ column 'Peringkat' and expiry status in the $9^{\text {th }}$ column 'Status Daluarsa'.

Table 4. Number of Programs at Various Ranks with Various Expiry Status (Excluding Expired)

\begin{tabular}{ccccc}
\hline Rank & \multicolumn{3}{c}{ Expiry Status } & Total \\
\cline { 2 - 4 } & $\begin{array}{c}\text { Not } \\
\text { expired } \\
\text { yet }\end{array}$ & $\begin{array}{c}\text { Reaccreditation } \\
\text { process }\end{array}$ & $\begin{array}{c}6 \text { months } \\
\text { prior to } \\
\text { expiry } \\
\text { date }\end{array}$ & \\
\hline A & 88 & 1 & 1 & 90 \\
B & 303 & 6 & 12 & 321 \\
C & 161 & 12 & 18 & 191 \\
Total & 552 & 19 & 31 & 602 \\
\hline Sournnnn
\end{tabular}

Source: processed by author

Based on the table above, the author decided to use the 88 programs which have an accreditation status of $\mathrm{A}$ and the status is not expired yet. Although this number represents only about $15 \%$ of the population (88 of 602 ), they are the front runners in terms of accreditation rank of bachelor's degree 
accounting program in Indonesia. Based on the information available on each program's website, the lists of courses in the curriculum for each of the 88 programs are inventoried. However, such information was not available for 28 programs, leaving out 60 programs as the sample. It is then analyzed whether there are any ethics-related course and whether the course is general or accounting-specific, as well as other features of the course.

\section{RESULT AND DISCUSSION}

Below is a table that classifies the 60 programs into geographical areas and status (public or private):

Table 5. Geographical Area and Status of 60 Programs

\begin{tabular}{cccc}
\hline Area & $\begin{array}{c}\text { Number of } \\
\text { Programs }\end{array}$ & Public & Private \\
\hline 1 & 1 & 0 & 1 \\
2 & 1 & 1 & 0 \\
3 & 15 & 3 & 12 \\
4 & 11 & 3 & 8 \\
5 & 6 & 3 & 3 \\
6 & 7 & 4 & 3 \\
7 & 11 & 7 & 4 \\
8 & 1 & 1 & 0 \\
9 & 3 & 3 & 0 \\
10 & 2 & 0 & 2 \\
11 & 1 & 1 & 0 \\
12 & 0 & 0 & 0 \\
13 & 1 & 1 & 0 \\
14 & 0 & 0 & 0 \\
Total & 60 & 27 & 33
\end{tabular}

Source: processed by author

Higher education providers are divided into 14 areas according to their location (geographical position) by the Indonesian government, through the Ministry of Research,
Technology and Higher Education. The 14 areas are:

1. North Sumatera

2. South Sumatera, Lampung, Bengkulu, Bangka \& Belitung Islands

3. Special Capital City District of Jakarta

4. West Java, Banten

5. Special Territory of Yogyakarta

6. Central Java

7. East Java

8. Bali, East Nusa Tenggara, West Nusa Tenggara

9. South Sulawesi, South East Sulawesi, Central Sulawesi, North Sulawesi, West Sulawesi, Gorontalo

10. West Sumatera, Riau, Jambi, Riau Islands

11. West Kalimantan, South Kalimantan, East Kalimantan, Central Kalimantan, North Kalimantan

12. Maluku, North Maluku

13. Aceh

14. Papua, West Papua

From the table, it can be deduced that the programs are concentrated in Java island, making up around $83 \%$ of the sample (50 divided by 60 programs). This is consistent with the fact that the island is considered by many as the most developed area and almost all good quality higher education providers are located there. However, this also highlights that there is a gap between the quality of education in Java island compared to those outside of the island. This issue is not within the scope of the current research, but it may warrant a specific attention. 
AKRUAL: Jurnal Akuntansi, volume 9, nomor 2, April 2018, (95-107)

With regards to the status, there are slightly more private institutions than public, with a comparison of $55 \%$ (33 divided by 60 ) to $45 \%$ (27 divided by 60). Whether or not the public/ private status causes any difference in accounting ethics course is not discussed in this research, however it may be an interesting and potential research topic, as the one conducted by Rutherford, Parks, Cavazos, White (2012).
Based on the list of courses available in the curriculum as retrieved from each of the program's website, the author tries to find any courses with the keyword 'ethics', whether offered as a general or accounting-specific course. This process then results in 4 categories of programs as summarized in Table 6.

Table 6. Ethics-Related Courses Offered by 60 Programs

\begin{tabular}{|c|c|c|c|c|}
\hline & $\begin{array}{l}\text { Programs that offer } \\
\text { general ethics course }\end{array}$ & $\begin{array}{l}\text { Programs that offer both general } \\
\text { and accounting-specific ethic } \\
\text { courses }^{2)}\end{array}$ & $\begin{array}{l}\text { Programs that offer accounting- } \\
\text { specific ethics course }\end{array}$ & $\begin{array}{l}\text { Programs that } \\
\text { offer neither } \\
\text { general nor } \\
\text { accounting- } \\
\text { specific course }\end{array}$ \\
\hline $\begin{array}{l}\text { Number of } \\
\text { programs }\end{array}$ & 9 & 4 & 36 & 19 \\
\hline Course names & $\begin{array}{l}\text { Ethics, Business } \\
\text { Ethics, Social Ethics, } \\
\text { Corporate } \\
\text { Governance \& } \\
\text { Islamic Business } \\
\text { Ethics }\end{array}$ & $\begin{array}{l}\text { General: } \\
\text { Ethics, Business Ethics, } \\
\text { Religion \& Ethics, Islamic } \\
\text { Business Ethics } \\
\text { Accounting-specific: } \\
\text { Accountant Ethics \& Corporate } \\
\text { Governance, Professional\& } \\
\text { Business Ethics, Professional } \\
\text { Ethics, Communication \& } \\
\text { Professional Ethics }\end{array}$ & $\begin{array}{l}\text { Professional Ethics \& Corporate } \\
\text { Governance, Professional } \\
\text { Ethics, Business \& Accounting } \\
\text { Profession Ethics, Business \& } \\
\text { Professional Ethics, } \\
\text { Professional\& Ethical } \\
\text { Standards, Leadership \& Ethics, } \\
\text { Business Law \& Professional } \\
\text { Ethics, Business and } \\
\text { Professional Ethics, Accounting } \\
\text { Profession Ethics, Professional } \\
\text { Ethics }\end{array}$ & \\
\hline $\begin{array}{l}\text { Placement in } \\
\text { the curriculum }\end{array}$ & $\begin{array}{l}\text { As early as in the } 2^{\text {nd }} \\
\text { semester, as late as in } \\
\text { the } 7^{\text {th }} \text { semester }\end{array}$ & $\begin{array}{l}\text { General: } \\
\text { As early as in the } 1^{\text {st }} \text { semester, } \\
\text { as late as in the } 7^{\text {th }} \text { semester } \\
\text { Accounting-specific: As early as } \\
\text { in the } 2^{\text {nd }} \text { semester, as late as in } \\
\text { the } 7^{\text {th }} \text { semester }\end{array}$ & $\begin{array}{l}\text { As early as in the } 2^{\text {nd }} \text { semester, } \\
\text { as late as in the } 8^{\text {th }} \text { semester }\end{array}$ & \\
\hline $\begin{array}{l}\text { Nature } \\
\text { (compulsory or } \\
\text { elective) }\end{array}$ & $\begin{array}{l}2 \text { programs design } \\
\text { the course as elective, } \\
\text { the remaining } 7 \text { as } \\
\text { compulsory }\end{array}$ & $\begin{array}{l}\text { Compulsory, except for } 1 \\
\text { program which designs the } \\
\text { course as compulsory for } \\
\text { Auditing concentration only }\end{array}$ & $\begin{array}{l}\text { Almost all programs set the } \\
\text { course as compulsory, but still } \\
\text { there exist who design it as an } \\
\text { elective or only compulsory for } \\
\text { certain concentration }\end{array}$ & \\
\hline $\begin{array}{l}\text { Prerequisite } \\
\text { courses }^{1)}\end{array}$ & $\begin{array}{l}\text { Introduction to } \\
\text { Business }\end{array}$ & $\begin{array}{l}\text { Accounting-specific: } \\
\text { Organizational Behavior in }\end{array}$ & $\begin{array}{l}\text { Introduction to Management \& } \\
\text { Business, Introduction to } \\
\text { Business, Capital Market, } \\
\text { Financial Management, } \\
\text { Business Law, Introduction to } \\
\text { Accounting, Auditing I, } \\
\text { Accounting Information } \\
\text { System, Strategy \& }\end{array}$ & \\
\hline
\end{tabular}


Internal Audit, Auditing II Organizational Performance

Management, Economics

Philosophy, Intermediate

Accounting II, Managerial

Accounting, Auditing II

1) Not every program has a complete course structure, including prerequisite courses, displayed on the website. Observations were made to those programs whose data is available.

${ }^{2)}$ This category is the intersection between the $1^{\text {st }}$ and $3^{\text {rd }}$ category, hence if the four categories are added up, the intersection must be deducted: $9+36-4+19=60$ programs

Source: processed by author

From table 6, it seems that approximately two third of the programs (41 out of 60) already have some sort of dedicated ethics-related course, whether as a general or accountingspecific course. This could indicate that the programs (or the universities in general) are aware of the importance of ethics-related course. The Indonesian government only requires 3 courses as government's compulsory, i.e. Indonesian Language, Religion and Civics (according to Act No. 12 of 2012 article 35 section 3) for bachelor's and diploma degree, yet some programs do have certain general-nature courses, such as Indonesian, English, Pancasila, as well as Ethics added into their curriculum as compulsory. They are willing to give slots for these courses, although not required by the government. Hence, this may indicate a commitment from academia to consider and acknowledge the subject matter as an important one, specifically Ethics in the context of this paper.

For the remaining 19 programs, it does not necessarily mean that they do not have general or accounting ethics topic of some sort in their curriculum. As previously explained in the research method section, only the keyword 'ethics' is used. It could be that these programs do not have dedicated/ stand-alone ethics course but the material is covered elsewhere. For example, generally speaking, there are subchapters/subtopics regarding ethics in financial accounting, management accounting, and auditing textbooks. Hence, although not taught as a distinct course, students do not lose their understanding of the importance of ethics as accountants, provided that the ethics-related materials are well covered. However, there is a possibility that these materials are only slightly covered and not prioritized by the lecturers due to limited time and space, that may result in ethics material be put secondary compared to technical accounting ones. Worse, there could be that ethics materials are not discussed at all in the classroom. Alternatively, programs may have a dedicated course which discusses ethics but under a different course name, i.e. ethics is taught in another subject which does not contain the word 'ethics' in the course name. Based on the list of courses inventoried, the possible courses are Corporate Governance, Education in Character and Anti-Corruption, Corporate Governance and CSR. Further analysis needs to be done regarding integrating ethics materials 
into other courses or under different course name, however it is not within the scope of this research, since it focuses only on providing an overview based on secondary source (website).

With regards to the naming of the course, there are not much differences observed, with professional or business ethics being the most common name observed. As for the placement in the curriculum, there is a variation among programs, ranging from the $1^{\text {st }}$ semester to last $\left(8^{\text {th }}\right)$ semester. Nevertheless, it should be noted that there is a difference between the course placement in the curriculum and the actual undertaking of that course by students. They could take the course earlier than suggested by the curriculum structure, provided that they already satisfy the prerequisite course. On the other hand, they could also postpone to take the course later than suggested.

Regarding the course nature, three classifications can be made. Firstly, compulsory for all students, which gives a strong signal of the program's commitment to make sure the students are exposed to ethics course. Secondly, compulsory for certain concentration (specialization) only. Some programs have concentration in which the students should choose, such as auditing, taxation, and financial accounting. In each of the concentration, there are compulsory courses that must be taken. Making ethics-related course as compulsory for certain concentration only could be questionable, i.e. may be interpreted that ethics is only important for that particular concentration only, whereas ideally it should be essential for all accounting students, regardless of what their concentration may be. Thirdly, design the course as elective, which could result in the perception of secondary nature of ethics course. Concerning the prerequisite courses, there is also a difference in terms of courses that must be satisfied before taking on the ethics-related subject. Some put accounting-related courses as the prerequisites, while some place a more business-related courses. It should be noted that only a few programs display prerequisite courses in their websites, so observations made were limited.

The discussion continues in terms of which approach (offering general only, accounting-specific only, or both) is best to teach ethics in accounting undergraduate curriculum. There is probably no clear-cut answer to this question. However, the author tries to give a suggestion by referring back to Table 1. There, the IAESB already set out learning outcomes for Professional Values, Ethics, and Attitudes, which consist of three competence areas: professional skepticism and professional judgment, ethical principles, and commitment to the public interest. The learning outcomes encompass both general as well as accounting-specific (related to the accounting profession) ethics, with more points are given towards the accounting profession ethics. Thus, the author is in favor of having a two-layered approach to teaching accounting ethics, i.e. a general one and an accounting-specific one, 
similar to what suggested by Levy and Mitschow (2008), Bean and Bernardi (2005), as well as Chawla, Khan, Jackson and Gray III (2015). The general one could be placed early in the curriculum with no prerequisites required, to serve as a foundation or basis to expose students about ethics in general. Meanwhile, the accounting-specific one should be placed late, probably in $6^{\text {th }}$ or $7^{\text {th }}$ semester, so that the students already have a comprehensive perspective with regards to the accounting profession and its responsibilities to the public. Required prerequisite courses will depend on each program policy and curriculum structure, to make sure that the course will not be available to be taken early. Some suggested contents for general ethics course are introduction to ethics, ethical principles and reasoning, philosophical aspects of ethics, cognitive processes and ethical decision making (Klein 2016; Mintz \& Morris 2014). Whereas for accounting-specific course, materials covered may include current ethical issues, professional codes of conduct and its application, ethical judgment and decisionmaking processes and models, corporate codes of ethics, whistleblower protection, record retention, ethical issues faced by the profession and contemplation and understanding of professional and moral obligations, relevant rules/ regulations for the accounting profession (Abdolmohammadi \& Reinstein 2012; Blanthorne 2017; Chawla, Khan, Jackson and Gray III 2015).
The need for a two-layered course structure is also supported by the learning outcomes for accounting bachelor's degree program as set in the Indonesian National Qualification Framework (Kerangka Kualifikasi Nasional Indonesia/ KKNI). In this framework, learning outcomes are divided into four aspects: attitude (sikap), knowledge mastery (penguasaan pengetahuan), specific skills (keterampilan khusus) and general skills (keterampilan umum). In the attitude aspect, there are two general ethics learning outcomes, i.e. (1) to highly appreciate humanity values in doing tasks according to religion, moral, and ethics and (2) to internalize values, norms, and academic ethics, as well as one accounting specific one: to internalize business and accounting profession ethical principles. In addition to that, there is also one accountingspecific learning outcome in the knowledge mastery aspect: to understand business ethics and accounting profession code of ethics. (https://kkni-kemenristekdikti.org/asset/pdf/draft/

\section{PROGRAMSTUDIS1AKUNTANSI.pdf)}

Nevertheless, the author acknowledges that a two-layered ethics course may not be feasible for some programs, as the curriculum is already quite packed with other accounting-skill courses. Several constraints that may be faced by the programs to organize a two-layered ethics course may include limited materials on the subject matter; lack of time, resources, knowledge, ability and expertise to teach ethics; lack of space in the curriculum; low level of 
priority (Blanthorne 2017; Graham, Kelly, Massey \& Van Hise 2014). In a study conducted by Marzuki, Subramaniam, Cooper and Dellaportas (2017), these inhibiting factors can be mitigated by examining variables that affect the extent to which ethics education is incorporated in the curriculum by accounting academics, such as accounting academics' attitudes towards ethics education, head of department support, peer support, and accounting academics' ethics teaching selfefficacy.

On the subject of the learning approach to accounting ethics, as can be referred back to Table 2, in general there are 3 approaches to ethics education: as a compulsory subject, as an elective subject, or integrating it with existing subjects. Each approach has its own strengths and weaknesses. In that table, there is also some suggested ways to neutralize the potential negatives of each approach so that the strengths of each can be highlighted. The author views that ethics-related materials should be designated as compulsory, given its importance, both in daily lives as well as in the accounting profession. To make it compulsory does not necessarily mean a stand-alone course. Although, to the extent that it is possible, having two compulsory stand-alone courses on ethics (general and accounting-specific), may be considered best. However, given some obstacles that may be faced by the programs to organize a stand-alone course on accounting ethics, as discussed in part 2, they may choose to integrate it with other courses. It should be noted that the program administrator must perform its supervising role to make sure the learning outcomes are actually covered. As Table 2 indicates, some potential negatives of the integration approach may include fragmented teaching and understanding, no solid theoretical foundations, intermittent and superficial treatment of the topic, and rhetorical approach without substance. In short, there is a risk that the coverage of the topic would be very shallow, or worse, is not actually taught in class (only put in the syllabus).

The debate of which approach to teaching accounting ethics (stand-alone vs. integrated) is best is not the focus of this paper, though it is an interesting topic. A consensus may not be achieved, as both approaches have their own advantages and disadvantages. The decision would also be based on the characteristics of each program and their resources availability, for example funding, appropriate instructors, etc. It is probably wise to shift the spotlight from which approach is best to making sure that the learning outcomes are covered well, either in a stand-alone course or to integrate it with other courses. As suggested by the KKNI, the emphasis is on the learning outcomes. Therefore, programs must map their courses with the learning outcomes in the form of a matrix, to make sure all learning outcomes are covered and to know what learning outcomes are expected from each course. In the end, by equipping accounting undergraduate students with the 
ethics of accounting profession, hopefully they will be able to perform their duty to serve public interest better once they become accountants.

Finally, it is worth noting that the author had some difficulties when collecting the data from each programs' website, e.g. difficulties in finding the list of courses in the curriculum as well as incompleteness of information in terms of prerequisites and the placement in the semester. Thus, the result should be interpreted cautiously as it relies on the reliability of data as displayed on the website. To conclude, this article is a preliminary research to get a grasp of accounting ethics course overview in accounting undergraduate curriculum in Indonesia; it is conducted to serve as a starting point for a broader research on the issue of interest, i.e. accounting ethics education development in Indonesia.

\section{CONCLUSIONS, IMPLICATIONS AND LIMITATIONS}

Based on the discussion above, it can be concluded that most programs that are observed already regard accounting ethics as important by designing a dedicated course. Some programs even have two stand-alone courses on ethics, i.e. general as well as accounting-specific. It is suggested that accounting ethics topic is covered in the curriculum, preferably in a stand-alone course, or integrating it into other courses if a stand-alone one is not feasible. The main emphasis should be put on making sure the learning outcomes related to accounting ethics are really covered during the learning process. As another suggestion, programs should improve their websites by making it more userfriendly, complete and up to date. Some relevant information that could be considered be put on it may include a complete structure of curriculum, prerequisite courses, short content/ description of each course.

There are several limitations of this research. First, it relies only on secondary data retrieved from the program's website. The website may not be up to date and the information displayed may be limited. Second, the author only searched for the keyword 'ethics' in the courses offered by each program. The fact that no course named under that particular keyword for some programs does not necessarily indicate that the topic on ethics is not taught at all in the curriculum. It could be that the topic is covered in other courses under a different name, or embedded in other courses; this research does not analyze the content of each course to see if ethics topic is actually taught under the 2 alternatives. Third, only programs which have accreditation status of $\mathrm{A}$ were included in this research.

As for further research, some areas that could be considered are, among others: assessment of ethics-related subjects' efficacy, research on different learning methods used in teaching ethics (pedagogical aspect), whether or not ethics-related materials are really taught in classrooms or just on paper, evaluation of the contents of ethics-related subject, differences 
between public vs. private universities or universities with religious affiliation vs. no religious affiliation in terms of ethics perception, and whether a stand-alone is better than an integrated ethics course.

\section{REFERENCES}

AACSB. (2016). Eligibility Procedures and Accreditation Standards for Accounting Accreditation.

AACSB. (2017). Eligibility Procedures and Accreditation Standards for Business Accreditation.

AACSB Ethics Education Task Force. (2004). Ethics Education in Business Schools.

Abdolmohammadi, M.J. \& Reinstein, A. (2012). Practising Accountants' Views of the Content of Accounting Ethics Courses and Course Effects on Attitudes and Behavior. Advances in Accounting Education: Teaching and Curriculum Innovations. Vol. 13, pp. 213-236. https://doi.org/10.1108/S10854622(2012)0000013014

Act No. 12 of 2012 on Higher Education.

Blanthorne, C. (2017). Designing A ThemeBased Ethics Course in Accounting. Advances in Accounting Education: Teaching and Curriculum Innovations. Vol. 20, pp. 135-140. DOI: https://doi.org/10.110 8/S1085462220170000020006

Bean, D.F. \& Bernardi, R.A. (2005). Accounting Ethics Course: A Professional Necessity. The CPA Journal. Vol. 75, No. 12, pp. 64-65.

Bean, D.F. \& Bernardi, R.A. (2007). Accounting Ethics Course: Do They Work? The CPA Journal. Vol. 77, No. 1, pp. 64-67.

Bernardi, R.A. \& Bean, D.F. (2006). Ethics in Accounting Education: The Forgotten Stakeholders. The CPA Journal. Vol. 76, No. 7, pp. 56-57.
Chawla, S.K., Khan, Z.U., Jackson, R.E., Gray III, A.W. (2015). Evaluating Ethics Education for Accounting Students. Management Accounting Quarterly, winter 2015. Vol. 16, No. 2, pp. 16-25.

Dellaportas, S. (2006). Making a Difference with A Discrete Course on Accounting Ethics. Journal of Business Ethics. Vol. 65, pp. 391-404. DOI: 10.1007/s10551006-0020-7

Duska, R., Duska, B.S. \& Ragatz, J. (2011). Accounting Ethics $2^{\text {nd }}$ edition. WileyBlackwell. DOI: https://doi.org/10.100 2/9781444395907

Graham, C.M., Kelly, P., Massey, D.W., \& Van Hise, J. (2014). One Size Does Not Fit All - Different Strategies for Teaching Accounting Ethics. Research on Professional Responsibility and Ethics in Accounting. Vol. 17, pp. 139-157.

DOI: $\quad$ https://doi.org/10.1108/S15740765(2013)000017008

https://banpt.or.id/direktori/prodi/pencarian_pro di, accessed on 14 December 2017.

http://kkni-kemenristekdikti.org/asset/pdf/draft/ 6160301_PROGRAM_STUDI_S1_AK UNTANSI.pdf, accessed on 13 December 2017.

IAESB. (2017). Handbook of International Education Pronouncements.

IAI. (2016). Kode Etik Akuntan Profesional.

IESBA. (2016). Handbook of the Code of Ethics for Professional Accountants.

IFAC. (2003). Rebuilding Public Confidence in Financial Reporting

IFAC. (2006). Approaches to the Development and Maintenance of Professional Values, Ethics and Attitudes in Accounting Education Programs.

Jackling, B., Cooper, B.J., Leung, P., Dellaportas, S. (2007). Professional Accounting Bodies' Perceptions of Ethical Issues, Causes of Ethical Failure and Ethics Education. Managerial Auditing Journal. Vol. 22, Issue 9, pp. 928-944. DOI: https://doi.org/10.1108 102686900710829426

Klein, G. (2016). Ethics in Accounting: A Decision Making Approach, Wiley. 
Klimek, J. \& Wenell, K. (2011). Ethics in Accounting: An Indispensable Course? Academy of Educational Leadership Journal. Vol. 15, No. 4, pp. 107-118.

Koumbiadis, N. \& Pandit, G.M. (2014). Has the AICPA Changed the Accounting Profession for Better or Worse? The Case of Educational Change. Journal of Accounting \& Organizational Change. Vol. 10, Issue 2, pp. 190-215. DOI: https://doi.org/10.1108/JAOC-07-20120054

Levy, D. \& Mitschow, M. (2008). Accounting Ethics Education: Where Do We Go from Here? Research on Professional Responsibility and Ethics in Accounting. Vol. 13, pp. 135-154. DOI:https://doi. org/10.1016/S15740765(08)13007-2

Marzuki, M., Subramaniam, N., Cooper, B.J., Dellaportas, S. (2017). Accounting academics' teaching self-efficacy and ethics integration in accounting courses: A Malaysian study. Asian Review of Accounting, vol. 25 issue 1, pp. 148-170 DOI: $\quad$ https://doi.org/10.1108/ARA-092015-0088

McDonald, G.M. (2004). A Case Example: Integrating Ethics into the Academic Business Curriculum. Journal of Business Ethics. Vol. 54, pp. 371-384. DOI: $\quad$ https://doi.org/10.1007/s10551004-1826-9
Mintz, S.M. \& Morris, R.E. (2014). Ethical Obligations and Decision Making in Accounting: Text and Cases $3^{\text {rd }}$ edition. .McGraw Hill.

Nicholson, C.Y. \& DeMoss, M. (2009). Teaching Ethics and Social Responsibility: An Evaluation of Undergraduate Business Education at the Discipline Level. Journal of Education for Business, pp. 213-218. DOI:https://doi.org/10.3200/joeb.84.4.2 13-218

Rezaee, Z., Szendi, J., Elmore, R.E. \& Zhang, R. (2015). Corporate Governance and Ethics Education: Viewpoints from Accounting Academicians and Practitioners. Advances in Accounting Education: Teaching and Curriculum Innovations. Vol. 13, pp. 127-158. DOI: https://doi.org/10.1108/S10854622(2012 )0000013011

Rutherford, M.A., Parks, L., Cavazos, D.E., White, C.D. (2012). Business ethics as a required course: Investigating the factors impacting the decision to require ethics in the undergraduate business core curriculum. Academy of Management Learning \& Education, vol. 11, no. 2, pp. 174-186 DOI: http://dx.doi.org/10. 5465/amle.2011.0039 